\title{
IDENTIFIKASI PERSEPSI MAHASISWA DALAM MENGAMBIL SERTIFIKASI AKUNTAN PROFESIONAL
}

\author{
Hidayatul Affifah ${ }^{1}$, Andi Kushermanto ${ }^{2}$, Arum Ardianingsih ${ }^{3}$ \\ 1,2,3 Universitas Pekalongan, Pekalongan, Indonesia \\ Email korespondensi: ${ }^{3}$ arumbundavina@gmail.com
}

\begin{abstract}
ABSTRAK
Tujuan penelitian ini ingin menguji persepsi niat mahasiswa untuk mengambil sertifikasi akuntan profesional sebagai Chartered Accountant (CA), Certified Internal Auditor (CIA), dan Certified Public Accountant (CPA). Subjek penelitian adalah mahasiswa program studi akuntansi Universitas Pekalongan. Sampel penelitian diambil dengan menggunakan random sampling pada mahasiswa Universitas Pekalongan. Data penelitian dikumpulkan dengan penyebaran kuesioner. Teknik analisis data menggunakan uji validitas, uji realiabilitas, uji asumsi klasik dan regresi linier berganda. Penelitian menemukan bahwa sikap dan harapan atas hasil memiliki hubungan positif terhadap niat mengambil sertifikasi akuntan profesional. Pemahaman tidak memiliki hubungan terhadap niat mengambil sertifikasi akuntan profesional. Hal ini mengimplikasikan bahwa untuk meningkatkan niat mahasiswa untuk menempuh sertifikasi akuntan profesional maka dapat dilakukan dengan meningkatkan pemahaman mahasiswa terkait sertifikasi akuntan profesional. Selain itu, untuk memotivasi mahasiswa juga perlu meningkatkan pemahaman harapan atas hasil jika menempuh sertifikasi akuntan profesional.
\end{abstract}

Kata Kunci: akuntan profesional; harapan atas hasil; persepsi; sikap

\section{ABSTRACT}

The purpose of this study was to examine the perception of students' intentions to take professional accountant certification as a Chartered Accountant (CA), Certified Internal Auditor (CIA), and Certified Public Accountant (CPA). The research subjects were students of the Universitas Pekalongan accounting study program. The research sample was taken using random sampling at Universitas Pekalongan students. Research data were collected by distributing questionnaires. The data analysis technique used validity test, reliability test, classical assumption test and multiple linear regression. The study found that attitudes and outcome expectations had a correlation on the intention to take professional accountant certification. While understanding does not have correlation on the intention to take professional accountant certification. This implies that to increase students' intention to take professional accountant certification, it can be done by increasing students' understanding of professional accountant certification. In addition, to motivate students, it is also necessary to increase understanding of expectations for results when taking professional accountant certification.

Keywords: attitude; expectations for results; perception; professional accountants

\section{KETERANGAN ARTIKEL}

Riwayat Artikel: diterima: 27 Maret 2021; direvisi: 16 Desember 2021; disetujui: 24 Desember 2021

Klasifikasi JEL: H89

Cara mensitasi: Affifah, H., Kushermanto, A., \& Ardianingsih, A. (2021). Identifikasi Persepsi Mahasiswa dalam Mengambil Sertifikasi Akuntan Profesional. JIAFE (Jurnal Ilmiah Akuntansi Fakultas Ekonomi), 7(2), $259-268$. https://doi.org/ 10.34204/jiafe.v7i2.3172 
Hidayatul Affifah: Identifikasi Persepsi Mahasiswa ...

\section{PENDAHULUAN}

Indonesia memiliki jumlah penduduk sekitar kurang lebih 210 juta jiwa pada akhir tahun 2019 dari Sabang sampai Merauke (Badan Pusat Statistik, 2020). Jumlah penduduk yang besar tentu seperti pisau bermata dua karena artinya jumlah sumber daya manusia besar tetapi jika tidak diimbangi dengan ketersediaan lapangan kerja akan menimbulkan angka penggangguran meningkat. Pemerintah berupaya mengambil kebijakan dengan wajib belajar dua belas tahun serta ditambah persyaratan mengambil sertifikasi tertentu jika ingin memasuki profesi tertentu. Profesi akuntan sebagai salah satu profesi dengan prospek yang baik tentu juga tidak lepas dari persyaratan sertifikasi. Peran akuntan dibidang keuangan perusahaan merupakan tugas dan tanggung jawab yang tidak mudah, karena akuntan memastikan terwujudnya akuntabilitas dan transparansi pengelolaan keuangan perusahaan.

Catatan Ikatan Akuntan Indonesia (IAI) sampai akhir tahun 2020 untuk lulusan akuntansi rata-rata berjumlah sekitar 35.000 akuntan dan memiliki sertifikasi baru sekitar 24.000 akuntan. Sumaryono \& Sukanti (2016) menyimpulkan bahwa akuntan pendidik, akuntan manajemen, akuntan pemerintah, dan akuntan publik adalah profesi yang dapat dipilih lulusan akuntansi. Pemahaman dan kesadaran yang kurang dari lulusan akuntansi tentang sertifikasi sebagai pengakuan kompetensi untuk lebih dihargai pada dunia kerja dan industri. Karena belum optimalnya sosialisasi ujian sertifikasi untuk mahasiswa yang dilakukan oleh perguruan tinggi maupun asosiasi profesi akuntansi (Purba \& Purba, 2016).

Penelitian-penelitian terdahulu tentang niat mahasiswa akuntansi untuk mengambil sertifikasi akuntan profesional lebih banyak dalam konteks penerapan Theory of Planned Behavior (TPB) yang merupakan pengembangan dari Theory Reasoned Action (TRA). Hasil penelitian Kurniasih (2013) dengan job expectation, cognitive style, referents untuk melihat hubungannya pada profesi akuntan publik. Penelitian Wratsari (2018) menguji variabel-variabel sikap, norma subjektif, kontrol perilaku persepsian, efikasi diri, dan harapan atas hasil yang memiliki hubungan dengan niat mengambil sertifikasi profesi akuntan.

Seorang akuntan dengan sertifikasi akuntan profesional diharapkan mampu mengelola laporan keuangan dan mengambil keputusan bisnis. Sertifikasi ini adalah bentuk pengakuan atas kompetensi keahlian, pengetahuan dan ketrampilan yang dimiliki seseorang. Penelitian ini memfokuskan pada pengambilan sertifikasi akuntan profesional dalam bidang, yaitu: (1) pengakuan kompetensi sebagai analis keuangan yaitu sertifikasi Chartered Financial Analyst (CFA); (2) pengakuan pendidikan, pengetahuan, pengalaman dan ketrampilan sebagai auditor internal, yaitu sertifikasi Certified Internal Auditor (CIA); dan (3) pengakuan pendidikan, wawasan atau pengetahuan baik softskill dan hardskill dibidang akuntansi sebagai sertifikasi Chartered Accountant (CA) yang dikeluarkan oleh Ikatan Akuntan Indonesia (IAI). Alasan konsen pada ketiga sertifikasi akuntan di atas adalah hasil observasi awal mahasiswa akuntansi yang ada di Universitas Pekalongan sebagian besar menginginkan berkarir sebagai analis keuangan dan auditor internal. Selain itu, CA lebih dikenal oleh mahasiswa akuntansi sehingga mereka tertarik dan berniat mengambil sertifikasi CA ini sebagai bentuk pengakuan kemampuan dan kompetensi yang mereka miliki.

Akuntan yang bersertifikasi akan dianggap lebih kompeten dibandingkan akuntan yang tidak memiliki sertifikasi. Informasi yang memadai mengenai sertifikasi akuntansi akan memberikan pemahaman komprehensif sehingga berdampak pada keinginan kuat dari mahasiswa untuk mengambil sertifikasi akuntan profesional. Beberapa hal yang mungkin dipertimbangkan oleh mahasiswa akuntansi untuk mengambil sertifikasi akuntan profesional, seperti CA, CIA ataupun CFA adalah impian atau harapan hasil pada masa yang akan datang. Harapan hasil diprediksi mampu membangun persepsi mahasiswa mengambil sertifikasi akuntan profesional. Keyakinan mahasiswa akan kemampuannya atau efikasi diri akan diwujudkan dalam bentuk sikap untuk mengambil sertifikasi akuntan profesional. Dengan demikian, tujuan penelitian ini adalah untuk mengidentifikasi hubungan sikap, pemahaman, dan harapan atas hasil terhadap niat mahasiswa mengambil sertifikasi akuntan profesional. 


\section{KAJIAN LITERATUR \\ Theory of Planned Behavior (TPB)}

Theory of Planned Behavior (TPB) atau Teori Perilaku Terencana memiliki asumsi dasar bahwa manusia kemungkinan besar akan mempertimbangkan informasi yang diterima baik secara langsung atau tidak langsung sebelum memutuskan bertindak atau bersikap serta menerima konsekuensi dari perilakunya (Jogiyanto, 2007). TPB adalah konsep dari perilaku seseorang yang dapat mengidentifikasi keyakinan dan pengendalian atas sesuatu yang akan terjadi, sehingga teori ini mampu membedakan antara perilaku seseorang berkehendak dan tidak berkehendak (Wellington dkk., 2006). TPB menjelaskan perilaku yang ditampilkan oleh individu timbul karena niat untuk berperilaku (behavior intention). Niat untuk berperilaku ditentukan oleh tiga macam kepercayaan, antara lain: (1) kepercayaan perilaku (behavior beliefs), yaitu keyakinan yang dimiliki seseorang yang melahirkan sikap suka atau tidak menyukai sesuatu; (2) kepercayaan normatif (normative beliefs), yaitu kepercayaan seseorang untuk bersikap sesuai norma atau aturan yang ada di masyarakat; (3) kepercayaan kontrol (kontrol beliefs), yaitu kepercayaan seseorang bahwa sikap dapat dipengaruhi oleh faktor pendukung sehingga sikap atau perilaku seseorang mengantarkan pada kinerja terbaiknya demikian juga sebaliknya.

\section{Persepsi, Niat, Sikap, Pemahaman, dan Harapan Atas Hasil}

Persepsi adalah pandangan atau rresponss yang diberikan seseorang atas informasi yang diterimanya. Bentuk respons dari seseorang adalah sikap atau tindakan. Proses pembentukan persepsi dipengaruhi oleh: (1) faktor perhatian dari luar, meliputi insensitas dan pengulangan informasi secara terus menerus; dan (2) faktor dari dalam (internal set factor), yaitu keinginan belajar secara terus menerus (Dewi \& Sari, 2010).

TPB (Theory of Planned Behavior) menjelaskan bagaimana sikap atau perilaku seseorang terbentuk dari keyakinan yang ada dalam dirinya. Niat adalah dorongan yang ada dalam diri dan akan berubah sesuai dengan situasi dan kondisinya. Sulistiani (2012) mengatakan bahwa niat adalah motivasi seseorang baik secara sadar maupun tidak sadar dan dapat mempengaruhi sikap dan perilaku seseorang. Niat yang teguh mampu menuntun seseorang mencapai tujuan hidupnya.

Sikap adalah kepecayaan (belief) ataupun perasaan negatif/positif dari seseorang dalam suatu waktu tertentu dan dapat membentuk kharakter atau kepribadian seseorang (Jogiyanto, 2007). Hidayat \& Nugroho (2010) menyatakan sikap adalah perasaan mendukung atau memihak (favorableness) dan atau perasaan tidak mendukung atau tidak memihak (unfavorableness) terhadap suatu objek yang akan disikapi. Konsekuensi sikap seseorang akan memberikan dampak positif atau negatif. Laksmi \& Suciati (2018), menjelaskan makin seseorang individu mempunyai penilaian obyektif dan baik terhadap suatu tingkah laku maka akan menghasilkan konsekuensi positif berupa sikap atau perilaku positif (favorable) terhadap perilaku tersebut, demikian juga sebaliknya.

Arisudana (2009) mendefinisikan pemahaman (comprehension) sebagaimana seseorang merekonstruksi pengetahuannya untuk menerangkan, membedakan, memperluas, memberikan contoh dan mendeskripsikan serta menuliskan sesuatu sesuai dengan apa yang telah direkonstruksinya. Pemahaman dari seseorang akan memudahkan untuk menyimpulkan atau menerangkan kembali atas objek yang dipahami. Pemahaman yang dimaksud adalah pemahaman mahasiswa terhadap sertifikasi akuntan profesional. Mahasiswa akuntansi harus mengumpulkan informasi terkait sertifikasi akuntan profesional kemudian menimbang atas manfaat yang dapat diperoleh dari sertifikasi tersebut. Pemahaman tentang hal ini adalah dengan membaca peraturan Menteri Keuangan Republik Indonesia Nomor 25/PMK.01/2014 tentang Akuntan Beregister Negara dan Undang-Undang Republik Indonesia Nomor 5 tahun 2011 Bagian Kedua Perizinan untuk menjadi Akuntan Publik Pasal 6. Kemudian informasi 
Hidayatul Affifah: Identifikasi Persepsi Mahasiswa ...

juga bisa diperoleh melalui laman website Ikatan Akuntan Indonesia (IAI) sebagai induk asosiasi Akuntan di Indonesia.

Harapan atas hasil adalah impian yang ada dalam diri seseorang sebagai tujuan dari sebuah keyakinan yang tertuang pada sikap ataupun perilaku secara kontinyu dan memberikan dampak positif. Harapan atas hasil terjadi karena seseorang mengharapkan hasil-hasil diperoleh berdasar pada pertimbangan-pertimbangan atas sebuah perilaku yang dituntut dari seseorang. Harapan akan hasil adalah manifestasi dari pemikiran ataupun keyakinan seseorang berbentuk perilaku tertentu dan biasanya mengarah pada hasil tertentu. Harapan atas hasil terjadi karena seseorang dapat perilaku secara normatif dan sesuai dengan keyakinannya sehingga mendapatkan hasil sesuai dengan ekspektasi atau harapannya.

\section{Hubungan Sikap Terhadap Niat Mahasiswa Mengambil Sertifikasi Akuntan Profesional}

Jogiyanto (2007) menyatakan bahwa sikap adalah kepercayaan (belief) atau keyakinan atas perasaan positif atau negatif dari seseorang untuk bersikap atau berperilaku sesuai ketentuan atau norma yang ada. Keyakinan mendukung atau tidak mendukung suatu perilaku pada seorang mahasiswa dalam mengambil sertifikasi akuntan profesional adalah perasaan berkaitan dengan suatu perilaku untuk membawa manfaat bagi mahasiswa mengambil sertifikasi akuntan profesional. Penelitian Dewi dkk. (2018) tentang faktor-faktor yang memiliki hubungan dengan niat pengambilan sertifikasi akuntan profesional ACCA, CA, CPA, yaitu sikap, norma subjektif, kontrol perilaku persepsian, dan pemahaman dengan populasi penelitian pada mahasiswa S1 program studi Akuntansi Fakultas Ekonomi Universitas Islam Indonesia, Universitas Gadjah Mada, dan STIE YKPN. Penelitian selanjutnya dilakukan oleh Qimyatussa'adah dkk. (2017) dengan mengambil populasi penelitian pada mahasiswa STIE YKPN. Hal ini menjelaskan bahwa sikap mahasiswa yang berniat mengambil sertifikasi akuntan ACCA memiliki pengaruh terhadap niat mahasiswa untuk mengikuti ujian sertifikasi ACCA. Penelitian yang dilakukan oleh Hatta \& Riduan (2017), menyebutkan bahwa norma subjektif pada sertifikasi akuntan profesional ACCA, CA dan CPA berpengaruh positif dan signifikan terhadap niat mahasiswa untuk mengambil sertifikasi akuntan profesional ACCA, CA dan CPA.

Sikap adalah cerminan dari keyakinan seseorang atas kondisi dan situasional yang ada. Ketika keyakinan yang ada dalam diri mahasiswa tentang mengambil sertifikasi akuntan profesional memberikan manfaat yang besar pada masa depan maka mereka akan memutuskan untuk berniat mengambil sertifikasi akuntan profesional ini. Berdasarkan penjelasan ini diajukan hipotesis pertama sebagai berikut.

\section{$\mathrm{H}_{1}$ : sikap memiliki hubungan positif terhadap niat mahasiswa untuk mengambil sertifikasi akuntan profesional.}

\section{Hubungan Pemahaman Terhadap Niat Mahasiswa Mengambil Sertifikasi Akuntan Profesional}

Pemahaman dapat diartikan tentang bagaimana seseorang menggali, menjelaskan, atau menerangkan, kemudian membuat kesimpulan dan melakukan generalisasi atas sesuatu sesuai dengan konstruksi pengetahuannya dilengkapi contoh nyata untuk mempertajam apa yang diketahui dengan tingkat kesesuaian kenyataan (Arisudana, 2009). Penelitian Dewi dkk. (2018) memperlihatkan niat mahasiswa untuk mengambil sertifikasi akuntan profesional makin besar jika dibarengi dengan pemahaman komprehensif terkait sertifikasi tersebut. Ketika mahasiswa memperoleh sertifikasi akuntan profesional maka akan memperoleh manfaat secara keseluruhan dalam hal peningkatan daya saing atas profesi akuntan. Ketika mahasiswa bisa membedakan, menerangkan, menyimpulkan dan memperluas informasi tentang sertifikasi akuntan profesional, mereka akan memiliki keyakinan untuk berniat mengambil sertifikasi akuntan profesional.

Dari uraian tersebut, peneliti mengajukan hipotesis kedua berikut ini. 
$\mathrm{H}_{2}$ : pemahaman memiliki hubungan positif terhadap niat mahasiswa untuk mengambil sertifikasi akuntan profesional.

\section{Hubungan Harapan atas Hasil Terhadap Niat Mahasiswa Mengambil Sertifikasi Akuntan Profesional} Harapan atas hasil merupakan suatu harapan atau keyakinan mengenai kegiatan yang sudah terlaksanakan dan dimanifestasikan dalam bentuk sikap atau perilaku (Qimyatussa'adah, 2017). Penelitian Wratsari (2018), menyatakan bahwa harapan atas hasil memiliki hubungan positif dengan sikap mahasiswa akuntansi untuk mengikuti ujian sertifikasi ACCA, sedangkan menurut Qimyatussa'adah (2017), membuktikan bahwa harapan atas hasil berpengaruh positif terhadap niat mahasiswa akuntansi untuk mengikuti ujian sertifikasi ACCA. Ketika mahasiswa akuntansi memiliki keyakinan bahwa sertifikasi akuntan profesional akan memberikan hasil dan manfaat yang lebih besar maka mereka akan cenderung berniat untuk mengambil sertifikasi akuntan profesional tersebut. Uraian ini membuat peneliti mengajukan hipotesis ketiga berikut ini.

$\mathrm{H}_{3}$ : harapan atas hasil memiliki hubungan positif terhadap niat mahasiswa untuk mengambil sertifikasi akuntan profesional.

Model penelitian dalam penelitian ini dapat digambarkan sebagai berikut.

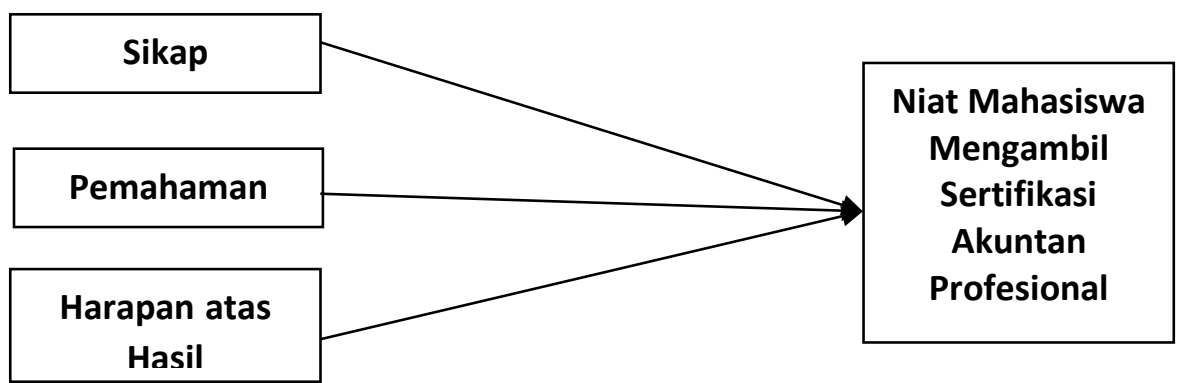

Gambar 1. Model Penelitian

\section{METODE PENELITIAN}

Jenis penelitian ini adalah penelitian kuantitatif dengan pendekatan korelasional yaitu penelitian yang akan menguji keterkaitan antar variabel baik dalam bentuk hubungan (Nurhayati, 2019). Variabel dependen dalam penelitian ini adalah niat mahasiswa untuk mengambil sertifikasi akuntan profesional. Penelitian ini memiliki dua variabel, yaitu dependen dan independen. Variabel dependen dalam penelitian ini adalah niat mahasiswa untuk mengambil sertifikasi akuntan profesional. Variabel ini diukur dengan menggunakan indikator sebagai berikut (1) keyakinan atas karir sebagai akuntan publik dan auditor internal; dan (2) keinginan berkarir sebagai akuntan profesional. Variabel independen (variabel bebas) adalah variabel yang nilainya tidak dipengaruhi oleh kelompok variabel lainnya.

Adapun yang menjadi variabel independen dalam penelitian ini, yaitu sikap, pemahaman, dan harapan atas hasil. Variabel sikap menggunakan indikator behavioral belief (nilai instriksi akuntan profesional, prospek dan pasar kerja) dan evaluation of behavioral belief. Variabel independen pemahaman menggunakan indikator berupa (1) pemahaman mengenai persyaratan untuk mengambil sertifikasi akuntan profesional dan (2) pemahaman terkait Undang-Undang Republik Indonesia Nomor 5 Tahun 2011. Variabel independen yang ketiga adalah harapan atas hasil diukur dengan menggunakan 
indikator (1) keuntungan karir; (2) mendukung perencanaan peluang kerja; dan (3) kematangan dalam karir.

Metode pengumpulan data kuantitatif berupa survei. Instrumen penelitian menggunakan kuesioner atau angket. Kuesioner yang disebar diukur menggunakan skala likert. Sampel penelitian ini menggunakan random sampling untuk memudahkan proses pengambilan data penelitian pada masa pandemi covid-19. Jumlah Mahasiswa Program Studi Akuntansi pada tahun akademik 2019/2020 ada sekitar 877 mahasiswa. Kuesioner yang disebar secara online diisi oleh responden sebanyak 185 orang. Penyebaran kuesioner dilakukan dengan cara broadcast di sosial media. Penyebaran dan pengisian kuesioner dilakukan mulai tanggal 17 Juni 2020 sampai tanggal 24 Juni 2020. Teknik analisis dalam penelitian ini menggunakan uji asumsi klasik berupa uji normalitas. Uji validitas dan reliabilitas data, uji hipotesis, dan uji regresi linier berganda.

\section{HASIL DAN PEMBAHASAN}

\section{Uji Validitas}

Pengujian validitas yang digunakan dalam penelitian ini adalah dengan uji korelasi Pearson, yaitu dengan melakukan korelasi bivariate antara masing-masing skor indikator dan total skor. Dikatakan valid apabila nilai total pada Pearson correlation sig. (2-tailed) di bawah 0,05.

Tabel 1. Hasil Uji Validitas

\begin{tabular}{|c|c|c|c|c|c|c|}
\hline & & X2.1 & $\times 2.2$ & X2.3 & X2.4 & TOT_X2 \\
\hline & Pearson Correlation & 1 & $0,474^{* *}$ & $0,373^{* *}$ & $0,467^{* *}$ & $0,755^{* *}$ \\
\hline \multirow[t]{3}{*}{$X 2.1$} & Sig. (2-tailed) & & 0,000 & 0,000 & 0,000 & 0,000 \\
\hline & $\mathrm{N}$ & 174 & 174 & 174 & 174 & 174 \\
\hline & Pearson Correlation & $0,474^{* *}$ & 1 & $0,391^{* *}$ & $0,434^{* *}$ & $0,759^{* *}$ \\
\hline \multirow[t]{3}{*}{$X 2.2$} & Sig. (2-tailed) & 0,000 & & 0,000 & 0,000 & 0,000 \\
\hline & $\mathrm{N}$ & 174 & 174 & 174 & 174 & 174 \\
\hline & Pearson Correlation & $0,373^{* *}$ & $0,391^{* *}$ & 1 & $0,443^{* *}$ & $0,754^{* *}$ \\
\hline \multirow[t]{3}{*}{$X 2.3$} & Sig. (2-tailed) & 0,000 & 0,000 & & 0,000 & 0,000 \\
\hline & $\mathrm{N}$ & 174 & 174 & 174 & 174 & 174 \\
\hline & Pearson Correlation & $0,467^{* *}$ & $0,434^{* *}$ & $0,443^{* *}$ & 1 & $0,757^{* *}$ \\
\hline \multirow[t]{3}{*}{$X 2.4$} & Sig. (2-tailed) & 0,000 & 0,000 & 0,000 & & 0,000 \\
\hline & $\mathrm{N}$ & 174 & 174 & 174 & 174 & 174 \\
\hline & Pearson Correlation & $0,755^{* *}$ & $0,759^{* *}$ & $0,754^{* *}$ & $0,757^{* *}$ & 1 \\
\hline \multirow[t]{2}{*}{ TOT_X2 } & Sig. (2-tailed) & 0,000 & 0,000 & 0,000 & 0,000 & \\
\hline & $\mathrm{N}$ & 174 & 174 & 174 & 174 & 174 \\
\hline
\end{tabular}

** Correlation is significant at the 0,01 level (2-tailed).

Nilai signifikasi butir item pada variabel sikap, pemahaman, harapan atas hasil dan niat mahasiswa mengambil sertifikasi akuntan profesional sebesar 0,000 , sehingga dapat disimpulkan semua butir item pertanyaan yang digunakan dalam penelitian ini adalah valid.

\section{Uji Reliabilitas}

Uji reliabilitas digunakan untuk mengetahui instrumen atau indikator yang digunakan dapat dipercaya atau andal sebagai alat ukur variabel. Apabila nilai cronbach's alpha (a) suatu variabel $>0,70$, pernyataan atau indikator yang digunakan oleh variabel tersebut dinyatakan reliabel. 
Tabel 2. Hasil Uji Reliabilitas

\begin{tabular}{ccc}
\hline Variabel & Cronbach Alpha & N \\
\hline X1 & 0,837 & 9 \\
X2 & 0,746 & 4 \\
X3 & 0,812 & 6 \\
Y & 0,756 & 3
\end{tabular}

Hasil uji reliabilitas atas variabel sikap sebesar 0,837, pemahaman sebesar 0,746, harapan atas hasil sebesar 0,812 dan niat mengambil sertifikasi akuntan profesional sebesar 0,756 , sehingga dapat disimpulkan semua variabel penelitian adalah reliabel.

\section{Uji Asumsi Klasik}

Uji asumsi klasik dalam penelitian ini menggunakan uji normalitas dengan menggunakan uji Kolmogorov-smirnov. Nilai sebesar 0,065 (di atas 0,050) yang menunjukkan data penelitian berdistribusi normal.

Tabel 3. Hasil Uji Normalitas

\begin{tabular}{llr}
\hline & & $\begin{array}{c}\text { Unstandardized } \\
\text { Residual }\end{array}$ \\
\hline $\mathrm{N}$ & Mean & 172 \\
Normal Parameters ${ }^{a, b}$ & Std. Deviation & 0,052 \\
& Absolute & 1,237 \\
Most Extreme & Positive & 0,100 \\
Differences & Negative & 0,087 \\
Kolmogorov-Smirnov Z & & $-0,100$ \\
Asymp. Sig. (2-tailed) & & 1,308 \\
\hline
\end{tabular}

a. Test distribution is Normal.

b. Calculated from data.

\section{Uji Regresi Berganda}

Tabel 4 menunjukkan hasil uji regresi untuk menemukan pengaruh dari variabel independen terhadap variabel dependen.

Tabel 4. Hasil Uji Regresi Berganda

\begin{tabular}{llrrrrr}
\hline Model & & \multicolumn{2}{c}{ Unstandardized } & Standardized & t & Sig. \\
\cline { 3 - 5 } & & \multicolumn{2}{c}{ Coefficients } & Coefficients & & \\
\cline { 3 - 4 } & (Constant) & $-0,818$ & 0,990 & & $-0,826$ & 0,410 \\
1 & TOT_X1 & 0,075 & 0,033 & 0,155 & 2,292 & 0,023 \\
& TOT_X2 & 0,080 & 0,052 & 0,099 & 1,541 & 0,125 \\
& TOT_X3 & 0,376 & 0,052 & 0,561 & 7,208 & 0,000
\end{tabular}

a. Dependent Variable: TOT_Y 
Hidayatul Affifah: Identifikasi Persepsi Mahasiswa ...

Hasil regresi linier berganda menunjukkan nilai signifikansi sebesar 0,023 lebih kecil $(<)$ dari pada 0,05 dengan nilai beta 0,075 . Artinya, hipotesis pertama diterima bahwa sikap memiliki hubungan positif terhadap niat mahasiswa untuk mengambil sertifikasi akuntan profesional. Hasil pengujian menunjukkan nilai signifikansi sebesar 0,123 lebih besar (>) daripada 0,050 dengan nilai beta 0,080. Artinya, hipotesis kedua ditolak bahwa pemahaman tidak memiliki hubungan terhadap niat mahasiswa untuk mengambil sertifikasi akuntan profesional. Hipotesis ketiga memiliki nilai signifikansi sebesar 0,000 lebih kecil $(<)$ dari pada 0,050 dengan nilai beta 0,376 . Hal ini berarti harapan atas hasil memiliki hubungan positif tehadap niat mahasiswa mengambil sertifikasi akuntan profesional.

\section{Hubungan Sikap Terhadap Niat Mahasiswa untuk Mengambil Sertifikasi Akuntan Profesional}

Sikap memiliki hubungan positif terhadap niat mahasiswa untuk mengambil sertifikasi akuntan profesional. Sikap pada sertifikasi akuntan profesional adalah kepercayaan individu apakah dengan mengambil sertifikasi akuntan profesional akan mendapatkan manfaat atau tidak bermanfaat bagi mahasiswa tersebut. Sikap adalah cerminan dari keyakinan yang melahirkan tindakan. Mahasiswa akuntansi Fakultas Ekonomi Universitas Pekalongan meyakini bahwa sertifikasi akuntan adalah pengakuan atas kemahiran ketrampilan, pengetahuan, dan wawasan seseorang di bidangnya. Pengakuan kompetensi tentu memberikan nilai tawar dan prospek karir jauh lebih baik jika dibandingkan dengan lulusan akuntansi yang tidak memiliki sertifikasi akuntan profesional. Mahasiswa akuntansi yang telah mengambil sertifikasi akuntan profesional akan makin mantap dalam menentukan profesi akuntan yang dipilihnya. Daya tawar atas pengakuan kompetensi menjadikan mereka berniat untuk mengambil sertifikasi akuntan profesional. Manifestasi daya tawar ini adalah gaji yang diperoleh akan lebih tinggi dibandingkan mereka dengan tidak memiliki sertifikasi akuntan profesional.

Hasil penelitian yang ini konsisten dengan penelitian Dewi dkk. (2018) dan Sumaryono \& Sukanti (2016) bahwa sikap pada sertifikasi akuntan profesional berpengaruh positif dan signifikan terhadap niat mahasiswa mengambil sertifikasi akuntan profesional CA, ACCA, dan CPA. Namun, hasil penelitian ini tidak konsisten dengan penelitan Laksmi \& Suciati (2018) yang menemukan bahwa niat mahasiswa untuk mengambil Chartered Accountant (CA) tidak dipengaruhi oleh sikap atas sertifikasi akuntan profesional.

\section{Hubungan Pemahaman Terhadap Niat Mahasiswa untuk Mengambil Sertifikasi Akuntan Profesional}

Pemahaman tidak memiliki hubungan terhadap niat mahasiswa untuk mengambil sertifikasi akuntan profesional. Hal ini dapat dijelaskan bahwa mahasiswa program studi akuntansi belum memiliki pemahaman yang komprehensif terkait peraturan-peraturan yang berlaku tentang sertifikasi akuntan profesional. Tingkat pemahaman yang dimaksud di atas adalah pemahaman mengenai persyaratan untuk mendapatkan sertifikasi CA, CIA dan CPA. Persyaratan ujian sertifikasi akuntan profesional lain seperti CPA, pengalaman di bidang akuntansi, peluang kerja yang di sediakan oleh CIA, gelar yang diperoleh setelah mengikuti ujian sertifikasi akuntan profesional serta perizinan menjadi akuntan publik ataupun auditor internal perusahaan.

Mahasiswa cenderung belum memahami dan melakukan persiapan matang atas ketrampilan, pengetahuan agar bisa diakui kompetensi ketika mengikuti ujian sertifikasi akuntan profesional sehingga banyak yang mengalami kegagalan dan membuat mereka tidak berniat mengikuti sertifikasi akuntan profesional. Mahasiswa dalam hal ini hanya memahami secara normatif tentang regulasi yang mengatur sertifikasi akuntan profesional tersebut. Hasil penelitian ini konsisten dengan penelitian Sumaryono \& Sukanti (2016) bahwa tingkat pemahaman tidak berpengaruh terhadap niat mahasiswa. 


\section{Hubungan Harapan Atas Hasil Terhadap Niat Mahasiswa untuk Mengambil Sertifikasi Akuntan Profesional}

Hipotesis ketiga diterima bahwa harapan memiliki hubungan positif terhadap niat mahasiswa untuk mengambil sertifikasi akuntan profesional. Harapan atas hasil dapat mempengaruhi tujuan individu dan usaha untuk mengimplementasikan tujuan tersebut selanjutnya berpengaruh pada niat (Wratsari, 2018). Mahasiswa berfikir tentang harapan hasil adalah ketika mereka selesai mengikuti sertifikasi akuntan profesional maka mereka akan mendapatkan seperti karir yang lebih baik, peluang kerja yang makin besar serta kematangan dalam karir. Makin besar harapan atas hasil yang akan di dapatkan oleh mahasiswa setelah mengikuti sertifikasi akuntan profesional maka akan makin besar pula niat mahasiswa untuk mengikuti sertifikasi akuntan profesional. Mahasiswa secara kritis telah berpikir bahwa sertifikasi akuntan profesional akan meningkatkan nilai tawar mereka di persaingan kerja dan dunia industry. Mahasiswa dalam hal ini akan berusaha lebih siap dengan mempoles kemampuan softskills dan hardskill mereka dibidang akuntansi dalam persiapan sertifikasi dan demi masa depan karir yang lebih baik.

Hasil penelitian ini konsisten dengan penelitian Wratsari (2018) dan Penelitian Qimyatussa'adah (2017) bahwa niat mahasiswa akuntansi mengikuti sertifikasi akuntan profesional ACCA dipengaruhi oleh harapan atas hasil yang akan diperoleh. Harapan atas hasil terjadi karena seseorang mengharapkan hasil-hasil diperoleh terutama pertimbangan-pertimbangan seberapa baik seseorang dapat melakukan perilaku yang dituntut (Jogiyanto, 2007).

\section{KESIMPULAN}

Mahasiswa harus mulai memikirkan pentingnya sertifikasi akuntan profesional untuk memberikan nilai tambah lulusan akuntansi. Hasil penelitian menunjukkan bahwa sikap dan harapan atas hasil memiliki hubungan positif terhadap niat untuk mengambil sertifikasi profesi akuntan dan pemahaman tidak hubungan terhadap niat tersebut. Hal ini menunjukkan bahwa para mahasiswa belum memiliki pemahaman yang komprehensif terkait manfaat dan peraturan-peraturan yang berlaku tentang sertifikasi akuntan profesional. Untuk itu, bagi Program Studi Akuntansi, khususnya di Universitas Pekalongan, umumnya di seluruh universitas yang memiliki prodi akuntansi, perlu untuk meningkatkan sosialisasi atau penyebaran informasi baik terkait manfaat, peraturan, maupun prosedur untuk menempuh sertifikasi akuntan profesional. Selain itu, perlu juga meningkatkan motivasi mahasiswa melalui harapan atas hasil dari menempuh sertifikasi akuntan profesional.

\section{DAFTAR PUSTAKA}

Arisudana, I. (2009). Intensi Berbagi Pengetahuan ditinjau dari Ekstraversi, Sikap, Norma Subjektif, dan Kontrol Perilaku yang dipersepsikan. Universitas Gadjah Mada.

Badan Pusat Statistik. (2020). Survey Kependudukan. https://www.bps.go.id/pressrelease/2021/01/21/1854/hasil-sensus-penduduk-2020.html.

Dewi, I. A. R. P., \& Sari, M. M. R. (2018). Persepsi Mahasiswa Akuntansi Reguler dan Non Reguler Universitas Udayana Terhadap Minat Mengikuti Pendidikan Profesi Akuntansi. E-Jurnal Akuntansi Universitas Udayana, 25(3), 2242-2268. https://doi.org/10.24843/EJA.2018.v25.i03.p23

Dewi, I. G. A. R. P., Putri, P. Y. A., \& Dewi, C. I. R. S. (2018). Niat Untuk Mengambil Sertifikasi Akuntan Dengan Pengujian Theory of Planned Behavior dan Teori Motivasi. Jurnal Ilmiah Akuntansi, 3(2), 171-192.

Hatta, M., \& Riduan, A. (2017). Niat Mahasiswa Akuntansi Berkarir sebagai Akuntan Di Luar Negeri: Pengujian Theory Of Planned Behavior. Jurnal Akuntansi, 7(2), 1-18. 
Hidayat, W., \& Nugroho, A. A. (2017). Studi Empiris Theory of Planned Behavior dan Pengaruh Kewajiban Moral pada Perilaku Ketidakpatuhan Pajak Wajib Pajak Orang Pribadi. Jurnal Akuntansi dan Keuangan, 12(2), 82-93.

Ikatan Akuntan Indonesia (IAI). (2014). Presentasi Chartered Accountant, Jumlah Lulusan Akuntansi. (Paper Presentation). http://www.iaiglobal.or.id/v03/files/file_ca/presentasi_ca/\#/60.

Jogiyanto, H. (2007). Sistem Informasi Keprilakuan Edisi Revisi. Yogyakarta: Andi

Kementrian Keuangan Republik Indonesia. (2014). Peraturan Menteri Keuangan Republik Indonesia Nomor 25/PMK.01/2014 Tentang Akuntan Beregister Negara. https://jdih.kemenkeu.go.id/fulltext/2014/25 PMK.01 2014Per.HTM

Kurniasih, S. (2013). Faktor-Faktor yang mempengaruhi Niat Mahasiswa Akuntansi untuk Berkarir sebagai Akuntan Profesional. Universitas Diponegoro.

Laksmi, A. C., \& Suciati, I. (2018). Factors Influencing the Intention to Obtain Accountant Certifications. The Indonesian Journal Of Accounting Research, 21(3), 347-362

Nurhayati, S. (2019). Metodologi Penelitian Praktis (Edisi 2). Pekalongan: Universitas Pekalongan.

Purba, S., \& Purba, D. H. P. (2016). Persepsi Mahasiswa Akuntansi Mengenai Faktor-Faktor Yang Membedakan Pemilihan Karir (Studi Kasus Fakultas Ekonomi Universitas Methodist Indonesia). Majalah IImiah Politeknik Mandiri Bina Prestasi, 5(2), 1-7.

Republik Indonesia. (2011). Undang-Undang Republik Indonesia Nomor 5 tahun 2011 Tentang Akuntan Publik. Lembaran Negara Republik Indonesia Tahun 2011 Nomor 51. https://www.dpr.go.id/dokjdih/document/uu/UU_2011_5.pdf

Sulistiani, D. (2012). Faktor-Faktor yang Mempengaruhi Niat Mahasiswa Akuntansi untuk Berkarir Sebagai Akuntan Publik: Aplikasi Theory of Planned Behavior (Studi Empiris pada Mahasiswa Universitas Diponegoro). Universitas Diponegoro.

Sumaryono., \& Sukanti. (2016). Faktor-Faktor yang Mempengaruhi Niat Mahasiswa Akuntansi untuk Mengambil Sertifikasi Chartered Accountant. Jurnal Profita, 2(7), 1-20

Qimyatussa'adah, Kusumaningrum, D., \& Kirowati, D. (2017). Faktor-faktor yang Mempengaruhi Persepsi Mahasiswa Jurusan Akuntansi untuk Memperoleh Gelar Sertifikasi Profesional Akuntansi. Jurnal Akuntansi dan Sistem Informasi, 2(1), 1-9. 